\title{
Relationships between Sense of Community, Authenticity, and Meaning in Life in Four Social Communities in France
}

\author{
Mathilde Moisseron-Baudé ${ }^{1,2, *} \mathbb{0}$, Jean-Luc Bernaud ${ }^{1}$ and Laurent Sovet ${ }^{3}$ \\ 1 Laboratoire du Centre de Recherche sur le Travail et le Développement (CRTD, EA4132), CNAM, \\ 75005 Paris, France; bernaud.j1@gmail.com \\ 2 VCR, École de Psychologues Praticiens de L'institut Catholique de Paris-Équipe D'accueil Religion, \\ Culture et Société, 75006 Paris, France \\ 3 Laboratoire de Psychologie et d'Ergonomie Appliquées (LaPEA), Université de Paris, \\ 92100 Boulogne-Billancourt, France; laurent.sovet@u-paris.fr \\ * Correspondence: mathildebaude@gmail.com
}

check for

updates

Citation: Moisseron-Baudé, M.;

Bernaud, J.-L.; Sovet, L. Relationships between Sense of Community, Authenticity, and Meaning in Life in Four Social Communities in France.

Sustainability 2022, 14, 1018. https:// doi.org/10.3390/su14021018

Academic Editors: Amelia Manuti, Antonino Callea and

Maria Luisa Giancaspro

Received: 27 November 2021

Accepted: 8 January 2022

Published: 17 January 2022

Publisher's Note: MDPI stays neutral with regard to jurisdictional claims in published maps and institutional affiliations.

Copyright: (c) 2022 by the authors Licensee MDPI, Basel, Switzerland. This article is an open access article distributed under the terms and conditions of the Creative Commons Attribution (CC BY) license (https:/ / creativecommons.org/licenses/by/ $4.0 /)$.

\begin{abstract}
This research explored the effects of sense of community and authenticity on meaning in life in social communities in France. The sample included one hundred participants from four social communities (i.e., political, religious, virtual learning, and mutual aid). The Meaning in Life Questionnaire, the Sense of Community Scale, and the Authenticity Scale were administered to the respondents. The correlational analyses indicated that sense of community and authenticity were more related to the presence of meaning ( $r=0.29$ and $r=0.54$, respectively) than to the search for meaning ( $r=-0.39$ and $r=0.03$, respectively). In addition, no interaction effects were found between sense of community and the three dimensions of authenticity, suggesting that the level of authenticity did not influence the relationships between sense of community and presence of or search for meaning. The practical and research implications of the study for social communities in the field of existential psychology were discussed.
\end{abstract}

Keywords: meaning in life; sense of community; authenticity; existential meaning; community

\section{Introduction}

The notion of community has no consensus definition and may be perceived differently from one country to another. In France, "community" is sometimes associated with negative connotations due to confusion with "communitarianism", compared to most English-speaking countries where the idea of community is rather one of "an asset to be preserved" [1]. In social sciences, it implies "the sharing of traditions, practices, activities, meanings, and values, linked to a significant degree of political involvement, usually in the same geographical region" [1]. Accordingly, it is relevant to examine the psychological benefits of community participation. More specifically, the current study aims to explore the effects of a sense of community and authenticity on meaning in life in several social communities in France.

\subsection{Conceptualizing Meaning in Life}

Meaning in life is a critical psychological resource that contributes to wellbeing, with positive effects observed on both physical [2] and mental health [3,4]. In recent decades, numerous studies have been conducted to identify antecedents and consequences of meaning in life [5]. Meanwhile, there have been major discussions about how it should be conceptualized in psychology. A scientific consensus has recently been established around a three-dimensional model combining coherence, purpose, and significance [6-10]. Following George and Park [6], meaning in life is defined as "the extent to which one's life is experienced as making sense, as being directed and motivated by valued goals, and as mattering in the world" (p. 206). Meaning in life, as distinct from meaning of life, focuses 
exclusively on the subjective experience of meaning and avoids the question of what might constitute a source of meaning [5].

Meaning in life is often understood by making a distinction between the presence of meaning and the search for meaning $[5,9]$. The presence of meaning describes "the extent to which people comprehend, make sense of, or see the significance in their lives, accompanied by the degree to which they perceive themselves to have a purpose, mission, or overarching aim in life" while search for meaning evokes "the degree to which people are trying to establish and/or augment their comprehension of the meaning, significance, and purpose of their lives" [11]. These two dimensions provide a better understanding of the complexity of how meaning in life is experienced. Previous research has shown that the presence of meaning is not always the opposite of the search for meaning. For instance, Dezutter et al. [12] demonstrated that several profiles could be described regarding the low or high levels of presence of and search for meaning. Similarly, a recent longitudinal study conducted over six months with 166 young adults in Hong Kong emphasized the relevance of looking at the presence of and search for meaning as independent indicators of meaning in life [13].

Numerous studies have highlighted the relevance of differentiating and searching for meaning in their relationships with other variables. For instance, positive links were found with subjective wellbeing [14], career adaptability [15], and passion for leisure [16], while negative links were shown with anxiety [17-19], uncertainty tolerance [20], and burnout [21]. In this study, we wanted to extend current literature by comparing the distinctive relationships of sense of community and authenticity with the presence of and search for meaning.

\subsection{Sense of Community}

McMillan [22] and McMillan and Chavis [23] are among the most cited references in the field of community psychology. They describe sense of community as "a feeling that members have of belonging, a feeling that members matter to one another and to the group, and a shared faith that members' needs will be met through their commitment to be together" [23]. McMillan and Chavis [23] developed a model with four dimensions, including membership, influence, integration, and the fulfillment of needs. This model continues to be used in contemporary research despite the fact that conceptualizations of sense of community and the methods for assessing this construct are still in debate [24-27]. Indeed, several psychometric scales have been derived from the four-dimensional model published by McMillan and Chavis [23]. The most commonly used is the Sense of Community Index, initially developed by Chavis et al. [28] and revised by Perkins et al. [29]. However, the validity of its factorial structure has often been questioned in different scientific contexts [24,26,30,31].

Several studies has demonstrated the benefits of sense of community on various socially related outcomes such as social wellbeing and community participation [32-35], social capital $[36,37]$, social autonomy $[33,38]$, social support $[39,40]$, and cohesion in society [41]. In addition, Mannarini et al. [42] showed that a high sense of community is associated with the value of universalism. Other studies have demonstrated positive correlations between sense of community and self-centered indicators such as psychological wellbeing [43-45], life satisfaction [46,47], self-compassion [48], and mental health [27,46,49,50]. Conversely, negative correlations between sense of community and self-criticism, isolation, excessive self-compassion [48], alienation, solitude [51], depression [50], stress [52,53], and suicide ideation [54] have been highlighted. According to Prezza et al. [45], sense of community gradually increases as individuals approach middle-age and move into later life.

There is a range of studies demonstrating that individuals are driven to create secure social bonds [55], which directly influence meaningful life [5]. Hicks and King [56,57] showed that positive social relationships, such as an awareness of social support, predicted meaning in life. However, further research is needed to explore more specifically the links between sense of community and meaning in life. 


\subsection{Authenticity}

Being authentic is: (A) to be in harmony with one's actual condition, physiological, emotional, and cognitive states, (B) to be aware of these states of being, and (C) to behave and to express one's emotions in ways that correspond and are appropriate to them [58]. In other terms, authenticity implies that "one acts in accord with one's true self, expressing oneself in ways that are consistent with inner thoughts and feelings" [59]. Based on the contribution of Rogers [60], Wood et al. [58] suggested a tripartite model including selfalienation, authentic living, and the influence of others. This model is currently the most frequently used for conceptualizing and assessing authenticity. Self-alienation relates to the relationship between A and B, dealing with the association between lived experiences and self-awareness. Too long a distance between the two dimensions is particularly alarming as it may reflect the difficulty to know who oneself is. Authentic life refers to the relationship between $\mathrm{B}$ and $\mathrm{C}$, which is the degree of congruence between one's psychological and emotional states, one's beliefs and values, and one's behaviors. Influence of others includes an individual's social environment and the way in which it conforms or not to other people's expectations. Thus, authentic life is more clearly an indicator of authenticity while self-alienation and influence of others are rather indicators of inauthenticity. Pinto et al. [61] demonstrates that inauthenticity-related indicators are predictors of aggressive behaviors.

Previous studies demonstrated that authenticity is significantly linked to wellbeingrelated outcomes. For instance, authentic life is positively related to wellbeing and negatively linked to anxiety, while self-alienation is positively associated with wellbeing and negatively associated with anxiety [58,62]. Overall, psychological wellbeing is positively correlated with authentic life and negatively correlated with self-alienation and the influence of others [58,62]. Consistently, being and knowing oneself are significant predictors of meaning in life $[5,63,64]$. In order words, authenticity is possibly considered as a critical ingredient to achieving a meaningful life $[55,65]$. A recent study confirmed that authenticity is a significant predictor of the presence of meaning in life [66]. Maintaining, or even increasing, states of authenticity over time also seems to be a necessary condition for sustainable improvement of meaning in life.

Contrary to the links between authenticity and meaning in life, the relationships between authenticity and sense of community have not been thoroughly studied. McMillan [67] stated that "without truth there can be no sense of community" (p. 316). As previously mentioned, authenticity is a fundamental human characteristic that has an impact on social and psychological health. In relation to sense of community, authenticity is negatively linked to negative affect $[39,68]$ and positively linked to positive affect $[46,58]$. A recent study was conducted among a sample of 402 Turkish students aimed at examining the relationships between authenticity and sense of community. Results revealed that sense of community was positively correlated with authentic life and negatively with self-alienation and influence of others. Accordingly, it seems relevant to explore the relationships between meaning in life, authenticity, and sense of community. More particularly, authenticity and sense of community are likely to interact together in their links with meaning in life.

\section{Objectives and Hypotheses}

The current study aims to examine the links between sense of community, authenticity, and meaning in life in relation to four social communities in France. Meaning in life is understood by making a distinction between the presence of and search for meaning [11]. Following our review of the literature, three main hypotheses were formulated:

Meaning in life and sense of community:

Hypothesis 1a (H1a). Presence of meaning is positively correlated to sense of community.

Hypothesis $\mathbf{1 b} \mathbf{( H 1 b ) . ~ S e a r c h ~ f o r ~ m e a n i n g ~ i s ~ n e g a t i v e l y ~ c o r r e l a t e d ~ t o ~ s e n s e ~ o f ~ c o m m u n i t y . ~}$ 
Meaning in life and authenticity:

Hypothesis 2a (H2a). Presence of meaning is positively correlated to authenticity.

Hypothesis $\mathbf{2 b}(\mathbf{H} \mathbf{2 b})$. Search for meaning is negatively correlated to authenticity.

The effect of interaction between sense of community and authenticity:

Hypothesis 3a (H3a). There is an interaction effect of sense of community by authenticity on the presence of meaning.

Hypothesis $\mathbf{3 b} \mathbf{( H 3 b )}$. There is an interaction effect of sense of community by authenticity on the search for meaning.

\section{Method}

\subsection{Participants}

The study was composed of one hundred participants who identified as belonging to a community. The sample comprised 51 women and 48 men (i.e., gender was not specified for one participant) aged from 19 to $73(M=43.74, S D=16.23)$. They were largely resident in the Paris metropolitan area (79\%). A majority of them had educational levels equivalent to four-year college (59\%) and were employees (50\%). Most representative marital statuses were single (39\%) and married (37\%).

The participants came from four different French communities; one political (41\%), one religious $(26 \%)$, one concerned with virtual learning $(21 \%)$, and another with mutual aid $(12 \%)$. No participant belonged to more than one community. Their community participation ranged from several days to more than sixty years $(M=10.27, S D=12.95)$. More than half of the respondents (54\%) joined their community because of a personal decision. Most of them had responsibilities within their community (54\%). They described their adherence to their communities in terms of shared values $(93 \%)$, commitments $(89 \%)$, or in relation to activities proposed $(86 \%)$. The time devoted to their communities was in a broad range: $43 \%$ dedicated less than $10 \mathrm{~h}$ per month, $44 \%$ between 10 and $40 \mathrm{~h}$ per month, and $13 \%$ more than $40 \mathrm{~h}$ per month. Based on participants' answers, the communities operated either by free entry (55\%) or by annual subscription (44\%), sometimes having several ways of functioning that operated at the same time. Members came together above all for meetings (85\%), for discussion/exchanges (63\%), and for shared activities (54\%).

\subsection{Measures}

The Meaning in Life Questionnaire was developed by Steger et al. [11] and adapted in a French version for the International Wellbeing Study [69]. It includes two subscales concerning the presence of meaning (e.g., "I understand my life's meaning") and the search for meaning (e.g., "I am seeking a purpose or mission for my life"). Each subscale comprises five items measured on a seven-point scale going from 1 (Absolutely untrue) to 7 (Absolutely true). To achieve acceptable fit indices, item 10 (i.e., "I am searching for meaning in my life") and two covariances between residual errors in the items were added: $\chi^{2}(24)=39.42$, $p=0.03, \mathrm{CFI}=0.964, \mathrm{TLI}=0.946, \mathrm{RMSEA}=0.079(0.028,0.121), \mathrm{SRMR}=0.009$. In this study, Cronbach's alphas were 0.83 and 0.85 , respectively, for the presence of and the search for meaning.

The Sense of Community Scale was developed by Saïas et al. [70]. It was built using a combination of items derived from the Sense of Community Index [29] and the Brief Sense of Community Scale [50]. The modifications were made in order to increase the relevance of items within the French culture. A typical example of an item is: "The members of this community share the same values." The SCS is unidimensional and comprises twelve items assessed using a five-point Likert scale from 1 (Completely disagree) to 5 (Completely agree). To achieve acceptable fit indices, two items (i.e., "I know the majority of 
my community's members" and "Very few community members know me") were removed and two covariances between residual errors in the items were added: $\chi^{2}(33)=45.41$, $p=0.07, \mathrm{CFI}=0.962, \mathrm{TLI}=0.948, \mathrm{RMSEA}=0.065(0.000,0.108), \mathrm{SRMR}=0.065$. In this study, Cronbach's alpha was 0.85 .

The Authenticity Scale was originally developed by Wood et al. [58] and adapted into French by Grégoire et al. [62]. It includes three subscales comprised of the influence of others (e.g., "Others influence me enormously"), authentic life (e.g., "I always defend what I believe in"), and self-alienation (e.g., "I feel disconnected from myself"). Each dimension is composed of four items measured against a seven-point Likert scale from 1 (Does not describe me at all) to 7 (Describes me very well). The initial model shows very good fit indices: $\chi^{2}(51)=55.16, p=0.32, \mathrm{CFI}=0.990, \mathrm{TLI}=0.987, \mathrm{RMSEA}=0.029(0.000,0.074)$, $\mathrm{SRMR}=0.055$. In this study, Cronbach's alphas were $0.84,0.70$, and 0.80 for the influence of others, authentic life, and self-alienation, respectively.

\subsection{Method}

As a pre-test, eight members of the target communities were asked to assess the comprehensibility of items. A large majority of items were perceived as fully understandable. However, minor adjustments were necessary for the SCS. All the scales were completed using an online form. Communities were selected purposefully using maximum variation sampling in order to capture a wide range of variations across traditions, practices, activities, meanings, and values for each community. Participants were recruited using the snowball method. Representatives of each community were initially contacted in person and were encouraged to share the announcement widely. Another fifth community (i.e., a humanist society) was also contacted, but the number of respondents was not sufficient to allow data collection. Different links for the online form were prepared (e.g., members of the religious received a unique link). However, the content was identical across the different versions of the online form.

Following article L1122-1 of the Public Health Code in France, each participant received and completed a written informed consent form. At the time of data collection, Institutional Review Board (IRB) did not exist at the first author's institution. Consequently, no ethical approval was asked. In France, ethical approval from an IRB is not a compulsory requirement for conducting research in social sciences [71]. Accordingly, the current study was conducted in full compliance with French regulations for research in social sciences.

\section{Results}

All the data was processed using the R software, version 3.6.0. Few missing values were observed $(<0.1 \%)$. MCAR Little's test revealed that data were missing completely at random $\left(\chi^{2}(33)=32.23, p=0.51\right)$. They were replaced using a multiple imputation method [72]. Analyses of data distribution for items and total scores showed moderate deviations from the normal curve. Consistently, the confirmatory factor analyses were conducted using the robust maximum likelihood method, while the correlation and regression analyses were based on non-parametric statistics.

\subsection{Correlational Analyses}

The Spearman correlations between all the measured variables are shown in Table 1. Presence of meaning was positively and significantly correlated with sense of community and the three dimensions of authenticity, with moderate to strong links of between $r=0.29$ $(p<0.05)$ for the influence of others, up to $r=0.54(p<0.01)$ for self-alienation. In other words, a high score for the presence of meaning was associated with a moderate sense of community, low influence of others, strong authentic life, and very low self-alienation. However, heterogeneous results were observed between the search for meaning and the other variables. In fact, only two dimensions of authenticity are significantly correlated with search for meaning: the influence of others $(r=-0.39, p<0.01)$ and self-alienation 
$(r=-0.32, p<0.01)$. Namely, where low search for meaning was associated with the high influence of others and self-alienation.

Table 1. Matrix of correlations between meaning in life, sense of community, and authenticity.

\begin{tabular}{|c|c|c|c|c|c|c|c|c|}
\hline & $M$ & $S D$ & 1 & 2 & 3 & 4 & 5 & 6 \\
\hline 1. Presence of meaning & 5.40 & 1.08 & - & & & & & \\
\hline 2. Search for meaning & 3.96 & 1.62 & -0.17 & - & & & & \\
\hline 3. Sense of community & 3.93 & 0.55 & $0.34^{* *}$ & 0.03 & - & & & \\
\hline 4. Influence of others 1 & 5.71 & 1.15 & $0.29 *$ & $-0.39^{* *}$ & 0.06 & - & & \\
\hline 5. Authentic life & 5.95 & 0.70 & $0.41^{* *}$ & -0.17 & $0.50 * *$ & $0.33^{* *}$ & - & \\
\hline 6. Self-alienation ${ }^{1}$ & 5.24 & 1.17 & $0.54^{* *}$ & $-0.32 * *$ & 0.17 & $0.58^{* *}$ & $0.48^{* *}$ & - \\
\hline
\end{tabular}

Note. $\mathrm{N}=100 .{ }^{*} p<0.05,{ }^{* *} p<0.01 .{ }^{1}$ The scores were inversed which means that high scores correspond to low influence of others or low self-alienation. The thresholds of significance were defined using Holm's method. Presence of meaning is positively and moderately correlated with self-alienation, authentic life, and sense of community, while search for meaning is negatively and moderately correlated with influence of others and self-alienation.

In addition, the age of the participants correlated positively but moderately with presence of meaning $(r=0.22, p<0.05)$, influence of others $(r=0.36, p<0.01)$ and selfalienation $(r=0.32, p<0.01)$, while a negative but moderate correlation was found with search for meaning $(r=-0.28, p<0.01)$. Seniority in the community was strongly related to age $(r=0.50, p<0.01)$. Homogeneous correlations were found with search for meaning $(r=-0.20, p<0.05)$, influence of others $(r=0.22, p<0.05)$ and self-alienation $(r=0.34, p<0.01)$. On the other hand, no significant correlation was found between sense of community and age $(r=-0.02, p=0.87)$ or with seniority in the community $(r=0.04$, $p=0.69$.

\subsection{Differences between the Communities}

The members of the four communities showed distinctive socio-demographic characteristics across age $\left(\chi^{2}(3)=24.48, p<0.01, \eta^{2}=0.22\right)$, gender $\left(\chi^{2}(3)=13.60, p<0.01\right.$, $\left.V_{\text {Cramer }}=0.37\right)$, marital status $\left(\chi^{2}(6)=18.30, p<0.01, V_{\text {Cramer }}=0.30\right)$, professional status $\left(\chi^{2}(15)=55.96, p<0.01, V_{\text {Cramer }}=0.43\right)$, and home-location $\left(\chi^{2}(3)=52.94, p<0.01\right.$, $\left.V_{\text {Cramer }}=0.73\right)$. More specifically, respondents from the virtual learning community were the oldest, the large majority of them being women. Participants from the religious community included the highest proportion of couples. Respondents belonging to the political community were predominantly students living in the Paris metropolitan area. In terms of community participation, significant differences were found for seniority $\left(\chi^{2}(3)=36.94\right.$, $\left.p<01, \eta^{2}=0.35\right)$ and membership $\left(\chi^{2}(3)=19.60, p<0.01, V_{\text {Cramer }}=0.44\right)$. Indeed, average seniority of members was observed among the religious community compared to the other communities while memberships to virtual learning community were predominantly the result of a personal initiative.

As presented in Table 2, the descriptive analysis of the differences and similarities between the four communities for all the variables measured, revealed that members of the religious community, on average, scored the highest for presence of meaning and lowest for search for meaning. Similarly, they had the highest average scores for a sense of community, authentic life, and lack of self-alienation. However, people from the mutual aid community had the highest average scores for freedom from the influence of others. The Kruskal-Wallis tests showed significant differences uniquely in relation to presence of meaning $\left(\chi^{2}(3)=12.59, p<0.01, \eta^{2}=0.10\right)$ and sense of community $\left(\chi^{2}(3)=15.65, p<0.01\right.$, $\left.\eta^{2}=0.13\right)$ with average effect sizes [73].

\subsection{The Effect of Interaction between Sense of Community and Authenticity}

Multiple regression analyses were conducted to examine more closely the influence of sense of community and authenticity on the presence of and search for meaning. For each dependent variable, three successive models were tested: (i) a linear model where sense of community is the predictive variable; (ii) a linear model where the three dimensions of 
authenticity are the predictive variables; and (iii) a multiple linear model where sense of community, the three dimensions of authenticity and their interaction effects are the predictive variables. The conditions of application of the models were examined by controlling the variance inflation factor, the homoscedasticity, and the autocorrelation in the residuals using the Durbin-Watson statistics. The results indicated that the model where presence of meaning was the predicted variable fitted well with the data. On the other hand, where search for meaning was the predicted variable, the model showed heteroscedasticity in the variance of the residuals. In this case, a Box-Cox transformation was needed to improve the fit of the model to the data.

Table 2. Means and standard deviations for meaning in life, sense of community, and authenticity for each community.

\begin{tabular}{|c|c|c|c|c|c|c|c|c|}
\hline & \multicolumn{2}{|c|}{$\begin{array}{l}\text { Political } \\
\text { Community } \\
\quad(n=41)\end{array}$} & \multicolumn{2}{|c|}{$\begin{array}{l}\text { Religious } \\
\text { Community } \\
\quad(n=26)\end{array}$} & \multicolumn{2}{|c|}{$\begin{array}{l}\text { Virtual Learning } \\
\text { Community } \\
(n=21)\end{array}$} & \multicolumn{2}{|c|}{$\begin{array}{l}\text { Mutual Aid } \\
\text { Community } \\
\quad(n=12)\end{array}$} \\
\hline & $M$ & $S D$ & $M$ & $S D$ & $M$ & $S D$ & $M$ & $S D$ \\
\hline 1. Presence of meaning & 4.99 & 1.29 & 5.98 & 0.73 & 5.50 & 0.79 & 5.38 & 0.69 \\
\hline 2. Search for meaning & 3.91 & 1.58 & 3.63 & 1.69 & 4.36 & 1.86 & 4.15 & 1.11 \\
\hline 3. Sense of community & 3.69 & 0.58 & 4.18 & 0.43 & 4.15 & 0.41 & 3.80 & 0.56 \\
\hline 4. Influence of others 1 & 5.28 & 1.27 & 5.11 & 1.33 & 4.96 & 0.81 & 5.81 & 0.81 \\
\hline 5. Authentic life & 5.82 & 0.70 & 6.15 & 0.74 & 5.89 & 0.61 & 6.00 & 0.76 \\
\hline 6. Self-alienation ${ }^{1}$ & 5.59 & 1.29 & 6.10 & 1.21 & 5.36 & 0.85 & 5.90 & 0.76 \\
\hline
\end{tabular}

Note. $N=100 .{ }^{1}$ The scores were inversed which means that high scores correspond to low influence of others or low self-alienation.

Table 3 shows a summary of the regression analyses of sense of community and authenticity on the presence of meaning. The first two models demonstrated that 11 and $30 \%$ of the variance in presence of meaning were explained by, respectively, sense of community $(F(1,98)=12.63, p<0.01)$, and authenticity $(F(3,96)=15.23, p<0.01)$. In model 2 , only the dimensions of authenticity relative to authentic life $(\beta=0.19, p=0.04)$, and self-alienation $(\beta=0.48, p<0.01)$ are significant at the minimum threshold $p<0.05$. In combination, these four independent variables explained $33 \%$ of the variance in presence of meaning where only sense of community $(\beta=0.21, p=0.03)$, and self-alienation $(\beta=0.46$, $p=0.03)$ had a significant role $(F(4,95)=13.07, p<0.01)$. However, the interaction effects between sense of community and the three dimensions of authenticity brought a negligible incremental variance $\left(\Delta R^{2}=0.01\right)$ that had no significant impact on the model $(F(3)=0.27$, $p=0.85)$.

Table 3. Regression analyses of sense of community and authenticity on presence of meaning.

\begin{tabular}{|c|c|c|c|c|c|c|c|c|}
\hline & \multicolumn{3}{|c|}{ Model 1} & \multicolumn{3}{|c|}{ Model 2} & \multicolumn{2}{|c|}{ Model 3} \\
\hline & $\beta$ & ES & $p$ & $\beta$ & ES & $p$ & $\beta$ & ES \\
\hline \multicolumn{9}{|c|}{ Block 1: Independent variables } \\
\hline Sense of community & 0.34 & 0.18 & $<0.01$ & & & & 0.22 & 0.20 \\
\hline Influence of others ${ }^{1}$ & & & & -0.03 & 0.10 & 0.80 & 0.02 & 0.10 \\
\hline Authentic life & & & & 0.19 & 0.14 & 0.04 & 0.07 & 0.16 \\
\hline Self-alienation ${ }^{1}$ & & & & 0.48 & 0.10 & $<0.01$ & 0.47 & 0.11 \\
\hline \multicolumn{9}{|l|}{ Block 2: Interactions } \\
\hline SC $\times$ Influence of others ${ }^{1}$ & & & & & & & -0.02 & 0.10 \\
\hline SC $\times$ Authentic life & & & & & & & -0.07 & 0.11 \\
\hline $\mathrm{SC} \times$ Self-alienation $^{1}$ & & & & & & & 0.07 & 0.12 \\
\hline$R^{2}$ adjusted & 0.11 & & & 0.30 & & & 0.31 & \\
\hline$\Delta R^{2}$ & & & & & & & 0.01 & \\
\hline
\end{tabular}

Note. $N=100$. SC $=$ Sense of community. ${ }^{1}$ The scores were inversed which means that high scores correspond to low influence of others or low self-alienation. Three models were tested to explore separately the effects of sense of community, authenticity, and the interaction effects between these two variables on presence of meaning. 
Table 4 shows a summary of all the regression analyses of sense of community and authenticity on search for meaning. Sense of community had a negligible and non-significant effect on the variance in search for meaning $(F(1,98)=0.16, p<0.01)$, unlike authenticity, which explains roughly $15 \%$ of the variance. More specifically, only the influence of others contributed significantly to the variance of search for meaning $(\beta=-0.27, p=0.02)$. The third model highlighted the absence of an interaction effect between sense of community and the three dimensions of authenticity with a negligible incremental variance $\left(\Delta R^{2}=0.02\right)$ and no significant contribution to the model $(F(3)=0.84, p=0.47)$.

Table 4. Regression analyses of sense of community and authenticity on search for meaning.

\begin{tabular}{|c|c|c|c|c|c|c|c|c|}
\hline & \multicolumn{3}{|c|}{ Model 1} & \multicolumn{3}{|c|}{ Model 2} & \multicolumn{2}{|c|}{ Model 3} \\
\hline & $\beta$ & SE & $p$ & $\beta$ & SE & $p$ & $\beta$ & SE \\
\hline \multicolumn{9}{|c|}{ Block 1: Independent variables } \\
\hline Sense of community & 0.04 & 0.51 & 0.69 & & & & 0.15 & 0.57 \\
\hline Influence of others 1 & & & & -0.27 & 0.28 & 0.02 & -0.28 & 0.29 \\
\hline Authentic life & & & & 0.02 & 0.41 & 0.82 & -0.11 & 0.47 \\
\hline Self-alienation ${ }^{1}$ & & & & -0.18 & 0.30 & 0.14 & -0.17 & 0.30 \\
\hline \multicolumn{9}{|l|}{ Block 2: Interactions } \\
\hline $\mathrm{SC} \times$ Influence of others ${ }^{1}$ & & & & & & & 0.07 & 0.28 \\
\hline SC $\times$ Authentic life & & & & & & & -0.02 & 0.31 \\
\hline SC $\times$ Self-alienation ${ }^{1}$ & & & & & & & 0.11 & 0.33 \\
\hline$R^{2}$ adjusted & -0.01 & & & 0.15 & & & 0.15 & \\
\hline$\Delta R^{2}$ & & & & & & & 0.02 & \\
\hline
\end{tabular}

Note. $N=100 . S C=$ Sense of community. ${ }^{1}$ The scores were inversed which means that high scores correspond to low influence of others or low self-alienation. Three models were tested to explore separately the effects of sense of community, authenticity, and the interaction effects between these two variables on search for meaning.

\section{Discussion}

The aim of this study was to examine the links between sense of community, authenticity, and meaning in life while making the distinction between presence and search for meaning [11]. The sample comprised four social communities in France: one political, one religious, one in virtual learning, and one in mutual aid.

The first hypothesis focused on the relationship between meaning in life and sense of community (H1a and H1b). This relationship was confirmed, but analyses demonstrated that sense of community was more closely associated to presence of meaning than to search for meaning. The result related to the relationship between sense of community and presence of meaning was consistent with previous studies [56,57]. Our results also highlighted the relevance of distinguishing presence of and search for meaning in their relationships with other constructs [14-21]. In addition, the positive and moderate to strong correlations of age with presence of and search for meaning were similar to the study conducted by Steger et al. [74].

The second hypothesis dealt with the link between meaning in life and authenticity $(\mathrm{H} 2 \mathrm{a}$ and $\mathrm{H} 2 \mathrm{~b})$. A positive correlation between meaning in life and the three dimensions of authenticity was confirmed. The presence of meaning was positively associated with authentic life and a negative perception of being influenced by others or self-alienation. Similarly, it was demonstrated that search for meaning was negatively correlated with the three dimensions of authenticity, two of which-the influence of others and self-alienationare significant. The results were similar to the study published by Wilt et al. [66] where high authenticity is positively associated with presence of meaning. Authenticity brings members of a community closer to what they really are, to their existential true selves [75], distancing them from alienating psychological patterns. Authentic life, designated by congruence between psychological states, values, and behaviors, in combination with true self-knowledge, determines meaning in life [63,64,76]. Since McMillan and Chavis [23], a factor determining how sense of community is defined has been identified, namely "influence," as it relates to power, whether that which is exercised by a member on the 
group or by the community on its members. Interest in the relationship between different influences and meaning in life has captured the attention of Jason et al. [77], who have shown that close relationships in various contexts, including that of a community, nurture a high degree of trust, which in turn generates new trust-relationships. Our study showed that the influence of others is important when individuals are searching for meaning. This approach supports the idea that the search for meaning is a quest to experience meaning in life [5]. Conversely, when members are aware of the meaningfulness of their lives, they are more liberated from and less dependent on the influence of others.

The third general hypothesis formulated focused on the interaction effect between sense of community and authenticity and how it affected presence of and search for meaning $(\mathrm{H} 3 \mathrm{a}$ and $\mathrm{H} 3 \mathrm{~b})$. In the same way, in the three models we investigated, no interaction effects between sense of community and the three dimensions of authenticity on presence of and search for meaning were found. The small size of the sample may be a critical limitation for testing such interaction effects.

Differences and similarities were observed across communities for community participation and profiles of respondents. For meaning in life to emerge as "a commonplace experience" [56], a social community must play an active role in the day-to-day life of individuals. It is likely to directly influence the subjective experience of members. Several notable results can be discussed. First, 44\% of participants dedicated between 10 and $40 \mathrm{~h}$ a month to their communities, which can be considered a substantial amount of time. Their commitment often comes with a willingness to take on responsibilities for $54 \%$ of respondents. Membership was considered by McMillan and Chavis's work [23] as primary among the four factors defining a sense of community, which requires dedication. It is noteworthy that the main motives that encourage individuals to join a community over and above the services and activities it may offer $(86 \%)$ or even more, the ideas and commitment of its members (89\%), is the opportunity to share common values (93\%). McMillan and Chavis [23] defined the integration and fulfillment of needs as another important determinant. It results from the satisfaction perceived by an individual regarding what a community brings in terms of resources, rewards, and shared values. The psychological rewards directly influence existential meaning and psychological wellbeing $[5,55,78]$. Values are known to be a source of meaning for individuals [79-81]. To our knowledge, only one recent study has established links between community and values, specifically universalism, one of the ten major values listed by Schwartz [82] as characterizing a human being. In fact, Mannarini et al. [42] showed that universalism encourages a sense of community and has an effect on how the community is perceived. Finally, our results showed that the members of the religious community reported the highest level of sense of community, followed by the virtual learning community, the mutual aid community, and the political community. For the presence of meaning, the order is the same. As far as McMillan and Chavis's [23] study highlighted, the last determinant is a common emotional link-the order can be traced to the history, or histories, of the community itself, especially as it has been proved that when crises are overcome together by a community's members, the links that tie them to the community are reinforced [83]. Conversely, when the organization of a community is confused, the cohesion between its members is affected [84,85].

\section{Limitations}

Several limitations should be considered. Firstly, a poor rate of participation has dramatically affected the generalization of the results in the target communities. Even though each community was initially of a reasonable sample size (i.e., calculated by the number of declared members), the final sample remained relatively small with a certain degree of heterogeneity in the profiles of the members. It would be relevant to continue the exploration of the relationships between sense of community and existential meaning among other groups or social communities. In addition, as a cross-sectional design, it was not possible to understand the relationships between sense of community, authenticity, and meaning in life from a causal point of view. Given the complexity of the relations 
between variables and variations in the level of presence of and search for meaning over time $[13,86]$, a longitudinal study would be more relevant. Furthermore, a correlational approach may be insufficient to understand the mechanisms behind the relationships between these variables. A phenomenological study is likely to offer an in-depth view of the experience of community participation and the process of meaning-making [87].

\section{Implications for Practice and Research}

The results suggest several practical applications in the field of existential psychology. For some people, a social community is considered a central part of themselves and their identity. Consistently, sense of community could be used as an existential theme within the context of counseling practices. Several existential themes could be explored with beneficiaries, such as meaning in life or authenticity, drawing on their sense of community in order to find a path towards an understanding of the existential true self [75]. For example, it would be relevant if counselors were to gather information about the actions and behaviors of beneficiaries that reveal their values and their fundamental personal beliefs [88]. Similarly, greater attention could be given to the extent to which a beneficiary's choices and experiences are self-determined or collectively shaped. Encouraging greater authenticity is likely to encourage being oneself and the development of positive psychological resources. Overall, such information would be helpful for clarifications and defining life priorities [89].

New career interventions could also be designed by applying the existential approach for career decision-making [90] or using meaning-centered approaches [91,92]. Accordingly, supporting beneficiaries in finding or creating meaning to their lives or works through connections with others and social communities may be particularly helpful for sustainable development $[93,94]$.

Author Contributions: M.M.-B. conceived the idea. M.M.-B. conducted the literature search and analysis. L.S. and M.M.-B. processed the data and wrote the paper. J.-L.B. contributed to the writing. All authors have read and agreed to the published version of the manuscript.

Funding: The present study was funded by Association pour les Progrès de l'Orientation (APO).

Institutional Review Board Statement: The study was conducted in accordance with the Declaration of Helsinki.

Informed Consent Statement: Informed consent was obtained from all subjects involved in the study.

Data Availability Statement: The data presented in this study are available on request from the corresponding author.

Acknowledgments: We would like to warmly thank the members of the social communities who participated in the study.

Conflicts of Interest: The authors declare that the research was conducted in the absence of any commercial or financial relationships that could be construed as a potential conflict of interest.

\section{References}

1. Schrecker, C. Quelques précisions concernant la notion de communauté [Some clarifications concerning the notion of community] In Introduction à la Psychologie Communautaire; Saïas, T., Ed.; Dunod: Malakoff, France, 2011; pp. 41-51.

2. Czekierda, K.; Banik, A.; Park CLLuszczynska, A. Meaning in life and physical health: Systematic review and meta-analysis. Health Psychol. Rev. 2016, 11, 387-418. [CrossRef] [PubMed]

3. Park, C.L. Making sense of the meaning literature: An integrative review of meaning making and its effects on adjustment to stressful life events. Psychol. Bull. 2010, 136, 257-301. [CrossRef] [PubMed]

4. Steger, M.F. Experiencing meaning in life: Optimal functioning at the nexus of spirituality, psychopathology, and wellbeing. In The Human Quest for Meaning: Theories, Research, and Applications; Wong, P.T.P., Ed.; Routledge: London, UK, 2012 ; pp. 165-184.

5. King, L.A.; Hicks, J.A. The science of meaning in life. Annu. Rev. Psychol. 2021, 72, 561-584. [CrossRef] [PubMed]

6. George, L.S.; Park, C.L. Meaning in life as comprehension, purpose, and mattering: Toward integration and new research questions. Rev. Gen. Psychol. 2016, 20, 205-220. [CrossRef]

7. Leontiev, D.A. Converging paths toward meaning. J. Constr. Psychol. 2017, 30, 74-81. [CrossRef] 
8. Martela, F.; Steger, M.F. The three meanings of meaning in life: Distinguishing coherence, purpose, and significance. J. Posit. Psychol. 2016, 11, 531-545. [CrossRef]

9. Sovet, L.; Bernaud, J.-L. Repères et débats conceptuels sur la psychologie du sens [Benchmarks and conceptual debates on the psychology of meaning]. In Sens de la Vie, Sens du Travail: Pratiques et Méthodes de l'Accompagnement en Education, Travail et Santé; Bernaud, J.-L., Lhotellier, L., Sovet, L., Arnoux-Nicolas, C., de Maricourt, P., Eds.; Dunod: Malakoff, France, 2019 ; pp. 13-28.

10. Wong, P.T.P. A decade of meaning: Past, present, and future. J. Constr. Psychol. 2017, 30, 82-89. [CrossRef]

11. Steger, M.F.; Frazier, P.; Oishi, S.; Kaler, M. The Meaning in Life Questionnaire: Assessing the presence of and search for meaning in life. J. Couns. Psychol. 2006, 53, 80-93. [CrossRef]

12. Dezutter, J.; Waterman, A.S.; Schwartz, S.J.; Luyckx, K.; Beyers, W.; Meca, A.; Kim, S.Y.; Whitbourne, S.K.; Zamboanga, B.L.; Lee, R.M.; et al. Meaning in life in emerging adulthood: A person-oriented approach. J. Personal. 2014, 82, 57-68. [CrossRef]

13. Chu, S.T.W.; Fung, H.H.L. Is the search for meaning related to the presence of meaning? Moderators of the longitudinal relationship. J. Happiness Stud. 2021, 22, 127-145. [CrossRef]

14. Li, J.-B.; Dou, K.; Liang, Y. The relationship between presence of meaning, search for meaning, and subjective well-being: A three-level meta-analysis based on the Meaning in Life Questionnaire. J. Happiness Stud. 2021, 22, 467-489. [CrossRef]

15. Yuen, M.; Yau, J. Relation of career adaptability to meaning in life and connectedness among adolescents in Hong Kong. J. Vocat. Behav. 2015, 91, 147-156. [CrossRef]

16. Zhang, S.; Shi, R.; Liu, X.; Miao, D. Passion for a leisure activity, presence of meaning, and search for meaning: The mediating role of emotion. Soc. Indic. Res. 2014, 115, 1123-1135. [CrossRef]

17. Abu-Raiya, H.; Sasson, T.; Russo-Netzer, P. Presence of meaning, search for meaning, religiousness, satisfaction with life and depressive symptoms among a diverse Israeli sample. Int. J. Psychol. 2021, 56, 276-285. [CrossRef]

18. Chen, Q.; Wang, X.-Q.; He, X.-X.; Ji, L.-J.; Liu, M.-F.; Ye, B.-J. The relationship between search for meaning in life and symptoms of depression and anxiety: Key roles of the presence of meaning in life and life events among Chinese adolescents. J. Affect. Disord. 2021, 282, 545-553. [CrossRef]

19. Yek, M.H.; Olendzki, N.; Kekecs, Z.; Patterson, V.; Elkins, G. Presence of meaning in life and search for meaning in life and relationship to health anxiety. Psychol. Rep. 2017, 120, 383-390. [CrossRef]

20. Morse, J.L.; Prince, M.A.; Steger, M.F. The role of intolerance of uncertainty in the relationship between daily search for and presence of meaning in life. Int. J. Wellbeing 2021, 11, 34-49. [CrossRef]

21. Krok, D. Can meaning buffer work pressure? An exploratory study on styles of meaning in life and burnout in firefighters. Arch Psychiatry Psychother. 2016, 1, 31-42. [CrossRef]

22. McMillan, D. Sense of Community: An Attempt at Definition; George Peabody College for Teachers: Nashville, TN, USA, 1976.

23. McMillan, D.W.; Chavis, D.M. Sense of community: A definition and theory. J. Community Psychol. 1986, 14, 6-23. [CrossRef]

24. Chipuer, H.M.; Pretty, G.M.H. A review of the sense of community index: Current uses, factor structure, reliability, and further development. J. Community Psychol. 1999, 27, 643-658. [CrossRef]

25. Mannarini, T.; Fedi, A. Multiple senses of community: The experience and meaning of community. J. Community Psychol. 2009, 37, 211-227. [CrossRef]

26. Nowell, B.; Boyd, N. Viewing community as responsibility as well as resource: Deconstructing the theoretical roots of psychological sense of community. J. Community Psychol. 2010, 38, 828-841. [CrossRef]

27. Talò, C.; Mannarini, T.; Rochira, A. Sense of community and community participation: A meta-analytic review. Soc. Indic. Res. 2014, 117, 1-28. [CrossRef]

28. Chavis, D.M.; Hogge, J.H.; McMillan, D.W.; Wandersman, A. Sense of community through Brunswik's lens: A first look. J. Community Psychol. 1986, 14, 24-40. [CrossRef]

29. Perkins, D.D.; Florin, P.; Rich, R.C.; Wandersman, A.; Chavis, D.M. Participation and the social and physical environment of residential blocks: Crime and community context. Am. J. Community Psychol. 1990, 18, 83-115. [CrossRef]

30. Long, D.A.; Perkins, D.D. Confirmatory factor analysis of the Sense of Community Index and development of a Brief SCI. J. Community Psychol. 2003, 31, 279-296. [CrossRef]

31. Obst, P.L.; White, K.M. Revisiting the Sense of Community Index: A confirmatory factor analysis. J. Community Psychol. 2004, 32, 691-705. [CrossRef]

32. Albanesi, C.; Cicognani, E.; Zani, B. Sense of community, civic engagement and social well-being in Italian adolescents. J. Community Appl. Soc. Psychol. 2007, 17, 387-406. [CrossRef]

33. Chavis, D.; Wandersman, A. Sense of community in the urban environment: A catalyst for participation and community development. Am. J. Community Psychol. 1990, 18, 55-81. [CrossRef]

34. Hughey, J.; Speer, P.W.; Peterson, N.A. Sense of community in community organizations: Structure and evidence of validity. J. Community Psychol. 1999, 27, 97-113. [CrossRef]

35. Wandersman, A.; Florin, P. Citizen participation and community organizations. In Handbook of Community Psychology; Rappaport, J., Seidman, E., Eds.; Springer US: New York, NY, USA, 2000; pp. 247-272. [CrossRef]

36. Putnam, R.D. Bowling Alone: The Collapse and Revival of American Community; Simon and Schuster: New York, NY, USA, 2000.

37. Wollebæk, D.; Selle, P. Participation and social capital formation: Norway in a comparative perspective. Scand. Political Stud. 2003, 26, 67-91. [CrossRef] 
38. Zimmerman, M.A.; Rappaport, J. Citizen participation, perceived control, and psychological empowerment. Am. J. Community Psychol. 1988, 16, 725-750. [CrossRef] [PubMed]

39. Oh, H.J.; Ozkaya, E.; LaRose, R. How does online social networking enhance life satisfaction? The relationships among online supportive interaction, affect, perceived social support, sense of community, and life satisfaction. Comput. Hum. Behav. 2014, 30, 69-78. [CrossRef]

40. Vieno, A.; Santinello, M.; Pastore, M.; Perkins, D.D. Social support, sense of community in school, and self-efficacy as resources during early adolescence: An integrative model. Am. J. Community Psychol. 2007, 39, 177. [CrossRef] [PubMed]

41. Wilkinson, D. The multidimensional nature of social cohesion: Psychological sense of community, attraction, and neighboring. Am. J. Community Psychol. 2007, 40, 214-229. [CrossRef] [PubMed]

42. Mannarini, T.; Rochira, A.; Ciavolino, E.; Salvatore, S. Individual and perceived community determinants of sense of community: The role of universalistic values. J. Community Psychol. 2019, 48, 623-637. [CrossRef] [PubMed]

43. Chipuer, H.M.; Bramston, P.; Pretty, G. Determinants of subjective quality of life among rural adolescents: A developmental perspective. Soc. Indic. Res. 2003, 61, 79-95. [CrossRef]

44. Pretty, G.M.H.; Conroy, C.; Dugay, J.; Fowler, K.; Williams, D. Sense of community and its relevance to adolescents of all ages. J. Community Psychol. 1996, 24, 365-379. [CrossRef]

45. Prezza, M.; Amici, M.; Roberti, T.; Tedeschi, G. Sense of community referred to the whole town: Its relations with neighboring, loneliness, life satisfaction, and area of residence. J. Community Psychol. 2001, 29, 29-52. [CrossRef]

46. Farrell, S.J.; Aubry, T.; Coulombe, D. Neighborhoods and neighbors: Do they contribute to personal well-being? J. Community Psychol. 2004, 32, 9-25. [CrossRef]

47. Prezza, M.; Costantini, S. Sense of community and life satisfaction: Investigation in three different territorial contexts. J. Community Appl. Soc. Psychol. 1998, 8, 181-194. [CrossRef]

48. Akın, U.; Akın, A. Examining the predictive role of self-compassion on sense of community in Turkish adolescents. Soc. Indic. Res. 2015, 123, 29-38. [CrossRef]

49. Long, D.A.; Perkins, D.D. Community social and place predictors of sense of community: A multilevel and longitudinal analysis. J. Community Psychol. 2007, 35, 563-581. [CrossRef]

50. Peterson, N.A.; Speer, P.W.; McMillan, D.W. Validation of a brief sense of community scale: Confirmation of the principal theory of sense of community. J. Community Psychol. 2008, 36, 61-73. [CrossRef]

51. Santini, Z.I.; Fiori, K.L.; Feeney, J.; Tyrovolas, S.; Haro, J.M.; Koyanagi, A. Social relationships, loneliness, and mental health among older men and women in Ireland: A prospective community-based study. J. Affect. Disord. 2016, 204, 59-69. [CrossRef]

52. Pfeil, U.; Zaphiris, P.; Wilson, S. Older adults' perceptions and experiences of online social support. Interact. Comput. 2009, 21, 159-172. [CrossRef]

53. Rains, S.A.; Young, V. A meta-analysis of research on formal computer-mediated support groups: Examining group characteristics and health outcomes. Hum. Commun. Res. 2009, 35, 309-336. [CrossRef]

54. Castellá Sarriera, J.; Bedin, L.M. Towards a socio-community model: A well-being approach. Univ. Psychol. 2015, 14, 1387-1398. [CrossRef]

55. Ryan, R.M.; Deci, E.L. On happiness and human potentials: A review of research on hedonic and eudaimonic well-being. Annu. Rev. Psychol. 2001, 52, 141-166. [CrossRef]

56. Hicks, J.A.; King, L.A. Positive mood and social relatedness as information about meaning in life. J. Posit. Psychol. 2009, 4, 471-482. [CrossRef]

57. Hicks, J.A.; Schlegel, R.J.; King, L.A. Social threats, happiness, and the dynamics of meaning in life judgments. Personal. Soc. Psychol. Bull. 2010, 36, 1305-1317. [CrossRef]

58. Wood, A.M.; Linley, P.A.; Maltby, J.; Baliousis, M.; Joseph, S. The authentic personality: A theoretical and empirical conceptualization and the development of the Authenticity Scale. J. Couns. Psychol. 2008, 55, 385-399. [CrossRef]

59. Harter, S. Authenticity. In Handbook of Positive Psychology; Snyder, C.R., Lopez, S.J., Eds.; Oxford University Press: Oxford, UK, 2002; pp. 382-394.

60. Rogers, C.R. Le Développement de la Personne [On Becoming a Person]; Dunod: Malakoff, France, 2018.

61. Pinto, D.G.; Maltby, J.; Wood, A.M.; Day, L. A behavioral test of Horney's linkage between authenticity and aggression: People living authentically are less-likely to respond aggressively in unfair situations. Personal. Individ. Differ. 2012, 52, 41-44. [CrossRef]

62. Grégoire, S.; Baron, L.; Ménard, J.; Lachance, L. The Authenticity Scale: Psychometric properties of a French translation and exploration of its relationships with personality and well-being. Can. J. Behav. Sci./Rev. Can. Des Sci. Comport. 2014, 46, 346-355. [CrossRef]

63. Schlegel, R.J.; Hicks, J.A.; Arndt, J.; King, L.A. Thine own self: True self-concept accessibility and meaning in life. J. Personal. Soc. Psychol. 2009, 96, 473-490. [CrossRef] [PubMed]

64. Sutton, A. Living the good life: A meta-analysis of authenticity, well-being and engagement. Personal. Individ. Differ. 2020, 153, 109645. [CrossRef]

65. McGregor, I.; Little, B.R. Personal projects, happiness, and meaning: On doing well and being yourself. J. Personal. Soc. Psychol. 1998, 74, 494-512. [CrossRef]

66. Wilt, J.A.; Grubbs, J.B.; Exline, J.J.; Pargament, K.I. Authenticity, presence of meaning, and struggle with ultimate meaning: Nuanced between-and within-person associations. J. Res. Personal. 2021, 93, 104104. [CrossRef] 
67. McMillan, D.W. Sense of community. J. Community Psychol. 1996, 24, 315-325. [CrossRef]

68. Li, Y.; Sun, F.; He, X.; Chan, K.S. Sense of community and depressive symptoms among older earthquake survivors following the 2008 earthquake in Chengdu China. J. Community Psychol. 2011, 39, 776-785. [CrossRef]

69. International Wellbeing Study. 2009. Available online: http:/ / www.wellbeingstudy.com/ (accessed on 26 November 2021).

70. Saïas, T.; Coulombe, S.; Loomis, C.; Beck, F. Validation de la Version Française du Brief Sense of Community Index. 2018, unpublished manuscript.

71. Brun-Wauthier, A.-S.; Vergès, É.; Vial, G. Les comités d'éthique pour les recherches non interventionnelles [Ethics Committees for non-interventional research]. In Éthique de la Recherche et Risques Humains; Martin, T., Ed.; Presses Universitaires de Franche-Comté: Besançon, France, 2014; pp. 79-107.

72. Van Buuren, S.; Groothuis-Oudshoorn, K. Mice: Multivariate Imputation by Chained Equations in R. J. Stat. Softw. 2011, 45, 1-67. [CrossRef]

73. Cohen, J. Statistical Power Analysis for the Behavioral Sciences, 2nd ed.; Lawrence Erlbaum Associates, Inc.: Mahwah, NJ, USA, 1988.

74. Steger, M.F.; Oishi, S.; Kashdan, T.B. Meaning in life across the life span: Levels and correlates of meaning in life from emerging adulthood to older adulthood. J. Posit. Psychol. 2009, 4, 43-52. [CrossRef]

75. Bernaud, J.-L. Introduction à la Psychologie Existentielle [Introduction to Existential Psychology]; Dunod: Malakoff, France, 2018.

76. Rivera, G.N.; Christy, A.G.; Kim, J.; Vess, M.; Hicks, J.A.; Schlegel, R.J. Understanding the relationship between perceived authenticity and well-being. Rev. Gen. Psychol. 2019, 23, 113-126. [CrossRef]

77. Jason, L.A.; Stevens, E.; Light, J.M. The relationship of sense of community and trust to hope. J. Community Psychol. 2016, 44, 334-341. [CrossRef]

78. Baumeister, R.F.; Leary, M.R. The need to belong: Desire for interpersonal attachments as a fundamental human motivation Psychol. Bull. 1995, 117, 497-529. [CrossRef]

79. Lecomte, J. Introduction à la Psychologie Positive [Introduction to Positive Psychology]; Dunod: Malakoff, France, 2010.

80. Reker, G.T.; Wong, P.T.P. Aging as an individual process: Toward a theory of personal meaning. In Emergent Theories of Aging; Birren, J.E., Bengtson, V.L., Eds.; Springer Publishing Company: New York, NY, USA, 1988; pp. $214-246$.

81. Schnell, T. The Sources of Meaning and Meaning in Life Questionnaire (SoMe): Relations to demographics and well-being. J. Posit. Psychol. 2009, 4, 483-499. [CrossRef]

82. Schwartz, S.H. Are there universal aspects in the structure and contents of human values? J. Soc. Issues 1994, 50, 19-45. [CrossRef]

83. Myers, A. Team competition, success, and the adjustment of group members. J. Abnorm. Soc. Psychol. 1962, 65, 325-332. [CrossRef]

84. Festinger, L. Laboratory experiments: The role of group belongingness. In Experiments in Social Process: A Symposium on Social Psychology; Miller, G.J., Ed.; McGraw-Hill: New York, NY, USA, 1950; pp. 31-46.

85. Mann, J.H.; Mann, C.H. The importance of a group task in producing group-member personality and behavior changes. Hum. Relat. 1959, 12, 75-80. [CrossRef]

86. Dezutter, J.; Luyckx, K.; Wachholtz, A. Meaning in life in chronic pain patients over time: Associations with pain experience and psychological well-being. J. Behav. Med. 2015, 38, 384-396. [CrossRef]

87. Smith, J.A.; Flower, P.; Larkin, M. Interpretative phenomenological analysis: Theory, method and research. Qual. Res. Psychol. 2009, 6, 346-347. [CrossRef]

88. Garg, N. Workplace spirituality and employee well-being: An empirical exploration. J. Hum. Values 2017, 23, 129-147. [CrossRef]

89. Arnoux-Nicolas, C.; Sovet, L.; Lhotellier, L.; Dupont, M.-P.; Fertin, F.; Bernaud, J.-L. Événements vécus et sens de la vie: Vers une différenciation des composantes de sens [Life events and meaning in life: Toward a distinction between the meaning's components]. Prat. Psychol. 2019, 25, 349-366. [CrossRef]

90. Cohen, B.N. Applying existential theory and intervention to career decision-making. J. Career Dev. 2003, 29, 195-209. [CrossRef]

91. Bernaud, J.-L.; Lhotellier, L.; Sovet, L.; Arnoux-Nicolas, C.; de Maricourt, P. (Eds.) Sens de la vie, Sens du Travail: Pratiques et Méthodes de l'Accompagnement en Education, Travail et Santé [Meaning of Life, Meaning of Work: Practices and Methods for Counseling in Education, Work, and Health]; Dunod: Malakoff, France, 2019.

92. González, L.A.G.; Léger, D.; Bourdages, L.; Dionne, H. Sens et Projet de Vie: Une Démarche Universitaire au Mitan de la Vie [Meaning and Life Project: An Academic Approach in the Middle of Life]; Presses de l'Université du Québec: Quebec City, QC, Canada, 2013.

93. Moisseron-Baudé, M.; Bernaud, J.-L.; Costalat-Founeau, A.-M. Une communauté sociale virtuelle médiatrice à la construction identitaire et au sens du travail [A virtual social community mediating the construction of identity and the meaning of work]. L'orientat. Sc. Prof. 2019, 48, 417-447. [CrossRef]

94. Moisseron-Baudé, M. The Role of Community Interactions in the Mechanism of Appropriation of Meaning for the Construction of One's Professional Career and One's Life. Ph.D. Thesis, CNAM-HESAM, Paris, France, 2020. Available online: http: //www.theses.fr/2020HESAC029 (accessed on 4 November 2020). 